\title{
Spatial and temporal description of water pollution status of Gajah Mungkur Reservoir Wonogiri, Central Java, Indonesia
}

\author{
WIRYANTO' \\ Department of Biology, Faculty of Mathematics and Natural Sciences, Universitas Sebelas Maret. Jl. Ir. Sutami 36A Surakarta 57126, Jawa Tengah. \\ Tel./Fax.+62-271-663375, "email: wirywiryanto@gmail.com
}

Manuscript received: 19 December 2015. Revision accepted: 27 October 2016

\begin{abstract}
Wiryanto. 2016. Spatial and temporal description of water pollution status of Gajah Mungkur Reservoir Wonogiri, Central Java, Indonesia. Biodiversitas 17: 888-893. Gajah Mungkur Reservoir (GMR) Wonogiri, Central Java, Indonesia was established with the purpose of: to control downstream flood, as hydropower generation, as fish farming, as a tourism destination and as an irrigation system in the dry season. As tourism destination and aquaculture, based on PPRI No. 82 2001, this reservoir is included in the category of class 2. The main purpose of this study was to determine the status of water pollution and activities of pollutant contributor to Gajah Mungkur Reservoir (GMR) Wonogiri spatially and temporally, in accordance with its purpose as the tourist destination and fish farming. Survey method study, purposive sampling method. The sampling was conducted at 8 stations (estuaries of Wuryantoro SubDrainage Basin (SubDAS), Alang-Solo Hulu Sub-Drainage Basin, Temon Sub-Drainage Basin, Keduang Sub-Drainage Basin, Tourism area, Fish culture area and aquaculture free zone, as well as the spillway or outlet), 4 times (in March, June, September and December) in the year 2011. The result shows that some reservoir water pollution parameters such as TSS, BOD $, \mathrm{COD}, \mathrm{Cu}, \mathrm{Mn}$ and Escherichia coli have been above the boundary required as class 2 water category based on PPRI No. 82 of 2001. Based on Storet calculations model, GMR Wonogiri waters are spatially distributed as heavily polluted on estuaries of Temon Sub-Drainage Basin and Keduang Sub-Drainage Basin, as moderately polluted on other 6 stations and temporally, on samplings on March 2011, GMR is heavily polluted, and the others are moderately polluted. Based on the calculation of Pollution Index spatial distribution, station 4 (Keduang estuary) is moderately polluted, and the other stations are lightly polluted, but based on the temporal distribution, the pollution status of GMR is lightly polluted. Pollutants flowing into GMR are dominated by wastes produced by households and industry activities from outside the reservoir (on the rainy season) and from KJA and tourism activities.
\end{abstract}

Keywords: Gajah Mungkur, pollution status, pollutant contributor activities

\section{INTRODUCTION}

Gajah Mungkur Reservoir (GMR) Wonogiri, Central Java, Indonesia was started to be built in 1975 and was completed in 1981. The purposes of the construction of GMR are (i) to overcome the flooding problems in the Bengawan Solo River downstream on the rainy season, (ii) to be the irrigation system in dry season, (iii) to be hydropower electric generator, (iv) to be water tourism area, and (v) to be aquaculture. The reservoir was built with an economic life estimation of 100 years, based on the estimation of actual erosion rate of $1.2 \mathrm{~mm} /$ year. From results of the monitoring, the erosion rate on Gajah Mungkur's catchment area is high, causing high sedimentation in the inundation area. The erosion rate is estimated at $8.58 \mathrm{~mm} /$ year (1982) and increasing into 26.0 $\mathrm{mm} /$ year (1985). With this erosion rate, it is estimated that the economic life of reservoir is only 27 years (Faculty of Geography UGM and SBRLKT Solo (1996). This requires the integrated management continuously to extend the life and function of the reservoir with the consideration of the environment.

Gajah Mungkur Wonogiri, is one of the reservoirs in Central Java, with a catchment area (DTA) which is located at $7^{\circ} 32^{\prime}$ LS-8015' S and 110004 'BT-110 018' BT. Administratively, the location is mostly located in
Wonogiri, Central Java and the other is in the district of Pacitan, East Java which in total consists of 21 districts and 224 villages, with total wide of 135,000 ha, 121,014 ha of land, and the remainder $(13,986 \mathrm{ha})$ is in the form of puddle (Sudibyakto et al. 2005). The area includes 7 SubDrainage Basin (SubDAS), namely; Wuryantoro SubDrainage Basin, Unggahan Sub-Drainage Basin, Alang Sub-Drainage Basin, Solo Hulu Sub-Drainage Basin, Temon Sub-Drainage Basin, Wiroko Sub-Drainage Basin, and Keduang Sub-Drainage Basin.

Gajah Mungkur is potentially tainted by the influx of waste activity as results of activities of inhabitants who stays on land above the reservoir (activities of households, industries, offices, farms, ranches, restaurants, markets, hotels, etc.), which supplies waste and community activities in the waters of the reservoir (cultivation fish, floating stalls and tourism). The great quantity of waste affects water pollution, so the quality of the waters is low. That situation needs to be controlled to maintain the water quality of the reservoir.

The problems that can be formulated in this study are: (i) how is water pollution status of Gajah Mungkur Reservoir Wonogiri, and (ii) what activities which contribute greatly to the pollution of Gajah Mungkur Reservoir Wonogiri. 


\section{MATERIALS AND METHODS}

Survey research, purposive sampling method. The research was conducted during 2011, with 4 times water sampling (March, June, September and December 2011) in 8 stations, namely; (i) estuary of Wuryantoro Sub-Drainage Basin (SubDAS), (ii) estuary of Alang-Solo Hulu SubDrainage Basin, (iii) estuary of Temon Sub-Drainage Basin, (iv) estuary of Keduang Sub-Drainage Basin, (v) KJA surrounding, (vi) the tourism zone, (vii) free zone (without KJA and tourism), and (viii) the outlet zone (spillway) (Figure 1).

Analysis of water samples (Alaerts and Santika 1987; Bapedal 1994; APHA 1995; AOAC 2005) was conducted in SubLab Chemistry and Biology, Laboratory Center of Mathematics and Natural Sciences, Universitas Sebelas Maret, Surakarta, Jawa Tengah, Indonesia, then the results were associated with the pollution parameter (Appendix of PPRI No. 82 of 2001). To determine the status of pollution, it was calculated with the method of Storet and Pollution Index (KepMNLH No. 115 of 2003). To determine the sources of pollution, an analysis of activities and pollutants that exceed the Water Quality Standards (class 2 based on PPRI No. 82 of 2001) should be carried out then they should be associated with the activities that produce or cause high pollution parameter.

\section{RESULTS AND DISCUSSION}

\section{Environmental parameters}

The result of water samples analysis of Gajah Mungkur Reservoir Wonogiri is completely presented in Table 1 .

Temp. (temperature); from the calculation results, water temperature ranges from 27.7 to $32.9{ }^{\circ} \mathrm{C}$. This temperature range is good for fish farming activities, in accordance with the statement of Effendi (2003).

Total Suspended Solids (TSS); almost the entire estuary of the Sub-Drainage Basin exceeds Water Quality Standard (WQS/BMA) (except Keduang Sub-Drainage Basin). This is because Keduang River provides water supply throughout the year so that most of the solids which are carried by the flowing water along the portion have already been precipitated in the river. In the dry season, the only river that feeds water into the reservoir is Keduang, so there is riptide on reservoir water. When the water flows back into the reservoir, it brings along the surface soil layer which is being eroded by water. The impact of these circumstances makes the TSS becomes larger than the other stations.

Total Dissolved Solids (TDS); TDS parameter at all sampling stations and sampling time was under water quality standard (BMA), namely under $1,000 \mathrm{mg} / \mathrm{L}$.

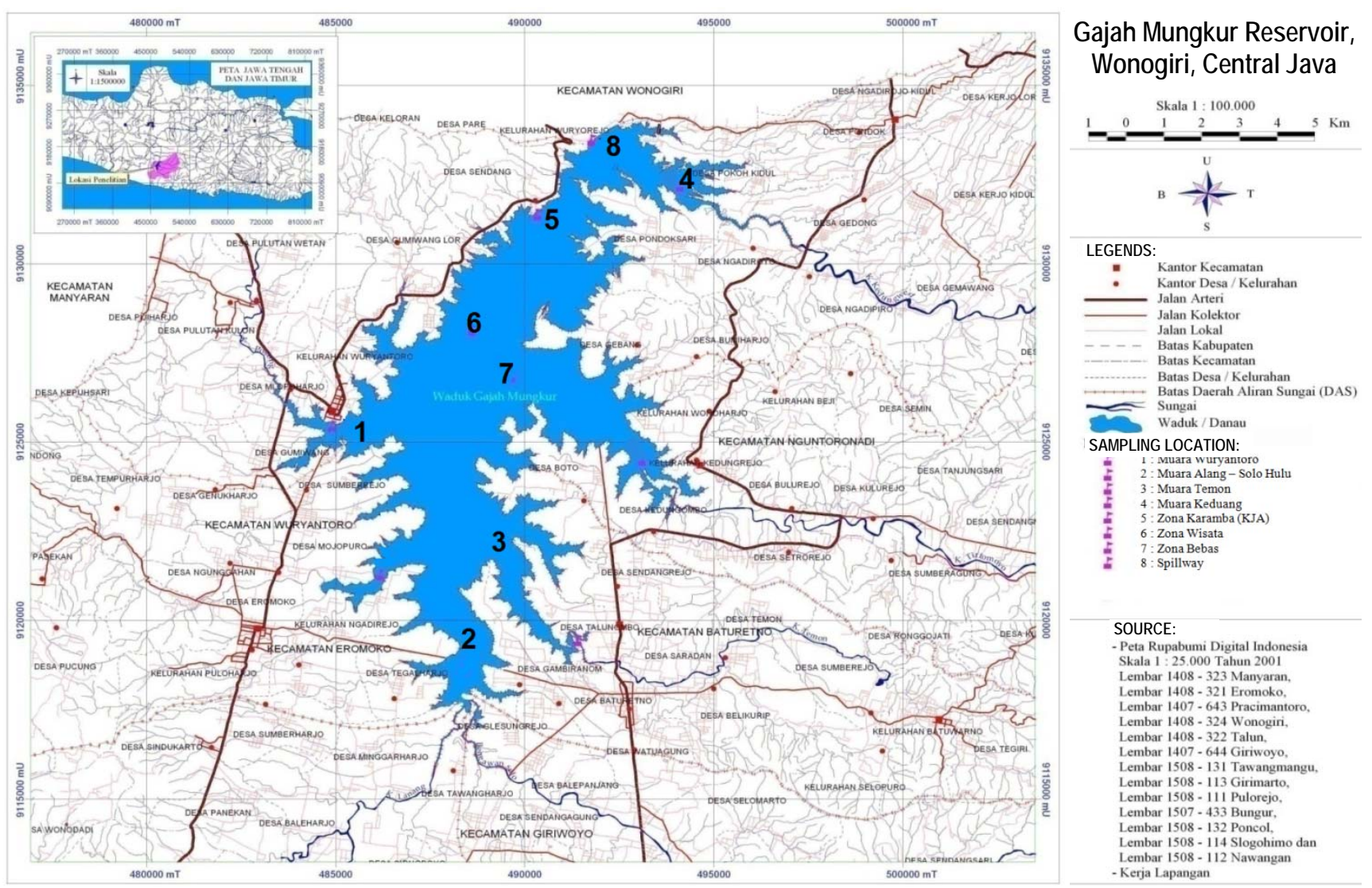

Figure 1. Location of water sampling of Gajah Mungkur Reservoir, Wonogiri, Central Java, Indonesia 
Table 1. Measurement of water environment parameters of Gajah Mungkur Reservoir, Wonogiri, Central Java, Indonesia which is Associated with Water Quality Standard (BMA) class 2 PPRI No. 82 of 2001

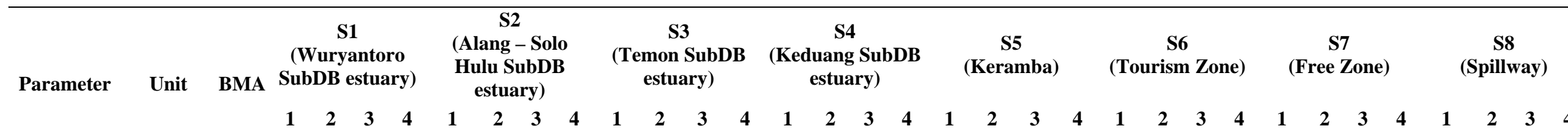

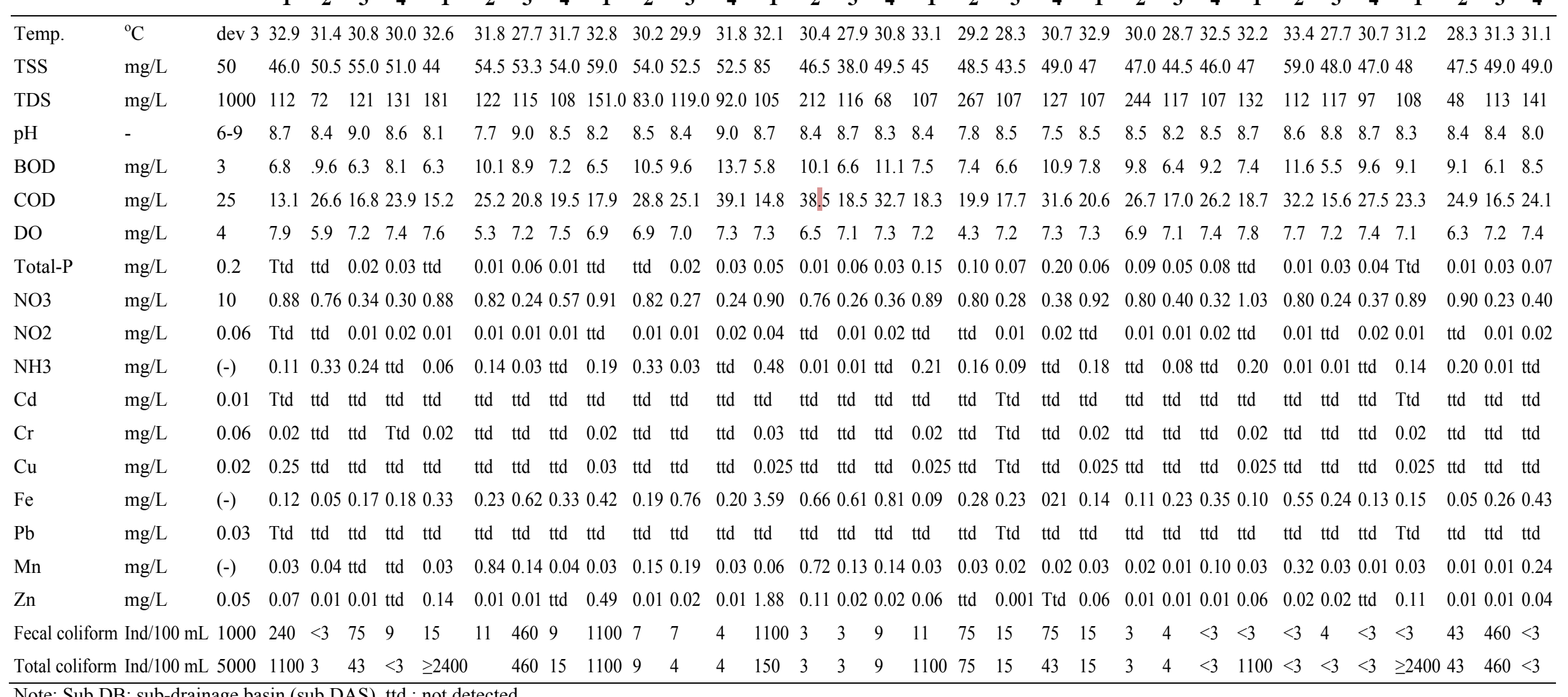


$p H$; the acidity $(\mathrm{pH})$ of water in reservoirs, in general, is between 6-9 (tolerance limit of BMA). This $\mathrm{pH}$ range can support the life of aquatic biota (Boyd 1982). In Wuryantoro Sub-Drainage Basin, Alang-Solo Hulu SubDrainage Basin and Temon Sub-Drainage Basin, are at the highest value (upper limit BMA of 9) in the dry season, it is possible due to the evaporation effect that lasts for a long time, leading to an increased concentrations of water and finally, $\mathrm{pH}$ is increased too. The situation is still within the limits of tolerance for the activities of living aquatic organisms.

Biological Oxygen Demand (BOD); in all stations and all the sampling time, the value of BOD exceeds BMA water class $2(>3 \mathrm{mg} / \mathrm{L})$. This indicates that the metabolic activity of aquatic organisms that occur in the reservoir water is high. This situation is possible because of the many organic compounds flowing into the waters of the reservoir, either from community activities in the area above the reservoir (especially in the rainy season) or from community activities in the reservoir itself (KJA, floating stalls, and Tourism), thus, it increases the metabolism of aquatic organisms.

Chemical Oxygen Demand (COD); at some stations, it is found that COD exceeds Water Quality Standard (WQS/BMA) class 2. It means that there are organic compounds which are hard to be decomposed biologically at that station, so the decomposing process should be done through a chemical one. This shows that there are organic compounds which are easy as well as hard to be decomposed biologically in the reservoir as a result of the accumulation of various human activities. At the station of the spillway, COD content is still under Water Quality Standard (WQS/BMA). This may be due to the flowing water which is always released through the spillway (outlet).

Dissolved Oxygen (DO); in all stations and at all the sampling time, DO value is above Water Quality Standard (WQS/BMA) namely $3 \mathrm{mg} / \mathrm{L}$. This demonstrates the high photosynthetic activity of aquatic flora and aeration of the atmosphere above. With a high content of $\mathrm{O}_{2}$, the availability of $\mathrm{O}_{2}$ in the waters is not perilous. Although BOD and COD are high, it has no effect on the content of $\mathrm{O}_{2}$ in the waters of GMR, so it does not disrupt the continuity of the normal life of the reservoir water biota. DO which is $<2 \mathrm{mg} / \mathrm{L}$ can lead to fish mortality (UNESCO/WHO/UNEP in Effendi 2003).

Cuprum $(\mathrm{Cu})$; Cuprum $(\mathrm{Cu})$ were found exceeding the Water Quality Standard (WQS/BMA) class 2 at all stations on first sampling in March 2011 (except at estuary of Alang-Solo Hulu Sub-Drainage Basin), but it cannot be found at the next sampling. It is possible due to the activity in the catchment area (CA/DTA) producing $\mathrm{Cu}$ which is directly disposed into the river, and then is carried by the flow of the river and headed into reservoir water. The trace of the source of $\mathrm{Cu}$ in the catchment area (CA/DTA) is needed to be done and the efforts to prevent the entry of such materials into the river, which then flows into the reservoir water, are needed to be carried out.
Zinc $(\mathrm{Zn})$, as well as $\mathrm{Cu}$, is found exceeding the Water Quality Standard (WQS/BMA) class 2 on the first sampling in March 2011. Therefore, it needs necessary attention for such activities that generate waste $\mathrm{Zn}$ and $\mathrm{Cu}$ simultaneously.

Fecal coliform (Escherichia coli) which is derived from human excrement and exceeding Water Quality Standard (WQS/BMA) class 2 is found at station 3 (Temon estuary) and station 4 (Keduang estuary) on the first sampling (March 2011) during the rainy season. It is possible since the habits of farmers who cultivate their paddy as well as dispense their excrement in the river flow. Despite these circumstances are incidentals, sufficient attention is needed to change their behavior that can cause environmental pollution.

\section{Pollution status}

The calculation results of the water pollution status of GMR which is based on KepMNLH No. 115 of 2003 are presented in Table 2 and Table 3 and also in Figure 2.

Table 2. Status of water pollution on Gajah Mungkur Reservoir, Wonogiri, Central Java, Indonesia at various stations (with Storet model calculations and Pollution Index of MNLH Ordinance No 115 of 2003)

\begin{tabular}{lclcl}
\hline \multirow{2}{*}{ Station } & \multicolumn{2}{c}{ Storet Method } & \multicolumn{2}{c}{$\begin{array}{c}\text { Pollution Index } \\
\text { Method }\end{array}$} \\
\cline { 2 - 5 } & Score & $\begin{array}{c}\text { Pollution } \\
\text { Level }\end{array}$ & $\begin{array}{c}\text { Pollution } \\
\text { Index }\end{array}$ & $\begin{array}{c}\text { Pollution } \\
\text { Level }\end{array}$ \\
\hline Wuryantoro & -20 & Moderate & 2.8280 & Light \\
Solo Hulu-Alang & -20 & Moderate & 2.2970 & Light \\
Temon & -36 & Heavy & 3.3286 & Light \\
Keduang & -35 & Heavy & 5.3319 & Moderate \\
KJA & -16 & Moderate & 2.2785 & Light \\
Tourism zone & -16 & Moderate & 2.3333 & Light \\
Free zone & -26 & Moderate & 3.4669 & Light \\
Spillway zone & -20 & Moderate & 2.3181 & Light \\
Average & -24 & Moderate & 3.0228 & Light \\
\hline
\end{tabular}

Table 4. The level of water pollution of Gajah Mungkur Reservoir, Wonogiri, Central Java, Indonesia at various sampling times

\begin{tabular}{lllcc}
\hline \multirow{2}{*}{ Sampling time } & \multicolumn{2}{c}{ Storet Method } & \multicolumn{2}{c}{$\begin{array}{c}\text { Pollution Index } \\
\text { Method }\end{array}$} \\
\cline { 2 - 5 } & Score & $\begin{array}{c}\text { Pollution } \\
\text { level }\end{array}$ & $\begin{array}{c}\text { Pollution } \\
\text { Index }\end{array}$ & $\begin{array}{c}\text { Pollution } \\
\text { level }\end{array}$ \\
\hline March 2011 & -35 & Heavy & 3.0169 & Light \\
June 2011 & -24 & Moderate & 2.2289 & Light \\
September 2011 & -15 & Moderate & 2.1331 & Light \\
December 2011 & -24 & Moderate & 2.6007 & Light \\
Average & -25.5 & Moderate & 2.4949 & Light \\
\hline
\end{tabular}

Note:

$\begin{array}{lll}\text { Pollution level } & \text { Storet Method } \begin{array}{l}\text { Pollution Index } \\ \text { Method }\end{array} \\ \text { Meet quality standard } & 0 & \mathrm{PI} \leq 1.0 \\ \text { Light polluted } & -1 \mathrm{~s} / \mathrm{d}-10 & 1.0<\mathrm{PI} \leq 5.0 \\ \text { Moderate polluted } & -11 \mathrm{~s} / \mathrm{d}-30 & 5.0<\mathrm{PI} \leq 10 \\ \text { Heavy polluted } & \geq-31 & <\mathrm{PI}\end{array}$




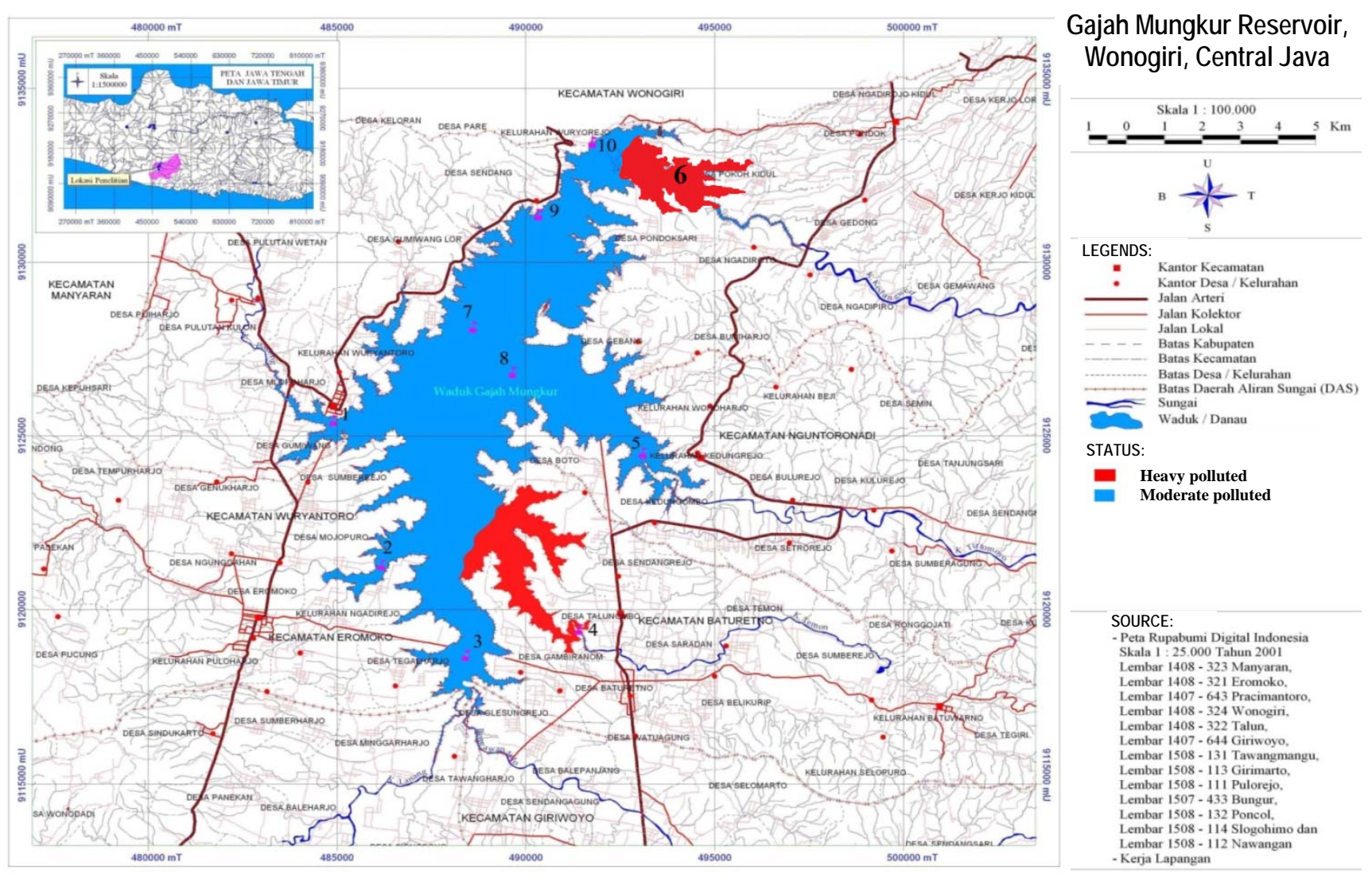

Figure 2. Status of water pollution in Gajah Mungkur Reservoir, Wonogiri, Central Java, Indonesia

Water pollution status of GMR is in the range of moderate to heavy polluted (based on the calculation of Storet model). Two observed stations have the status of heavy polluted (estuaries of Keduang River and Temon River). Major contribution to pollution is the presence of organic materials (either easy to be decomposed or hard to be decomposed), causing the requirement of $\mathrm{O}_{2}$ to decompose them (BOD and COD become high), and it becomes worse due to the availability of metal pollutants namely $\mathrm{Cu}$ and $\mathrm{Zn}$ that come from the workshop activities in the catchment area (DTA), that finally flows into the water of GMR. Based on the calculation model of Pollution Index (IP), the pollution is in the range of light polluted to moderate polluted. This indicates that the various activities carried out by the community, both in the catchment area (DTA) and inside the reservoir, has not caused significant pollution (can be tolerated). Nevertheless, caution must be taken in order not to increase activity that can increase the formation of waste which in turn will cause an increase in the pollution status of GMR.

Based on the calculation of parameters exceeding the Water Quality Standard (WQS/BMA) in GMR on sampling of March, June, September and December 2011, there is a conclusion that the result, as shown in Table 4, shows that only sampling in March GMR was on the status of heavy polluted, while on other sampling times, it was only moderate polluted. This happened due to the entry of waste from many activities in the Catchment Area (DTA), so the pollution status WG Reservoir was increased. But with the IP model calculation, it gave a better result, namely from the calculation result of 4 sampling times, all was in light polluted status.

Differences in the calculation results for the pollution status of the same data by different methods (methods Storet and Pollution Index contained in the Decree of the Ministry of Environtment, KepMNLH No. 115 of 2003) can raise doubts against the effectivity of pollution analysis of a body of water. This situation will affect the businesses or activities that throw their waste directly into the water body by desire or choose the status analysis of water pollution by using one of the analysis methods which is more profitable for them.

Differences in status of water pollution will affect the biodiversity in it, both the physical and genetic characteristics. For organisms that can withstand environmental changes, they will be able to continue to grow and continue to do their life activity, while those who are not able to withstand can do a migration or become extinct. Although this polluting activity has happened for a very long time, but from now on, the preservation of biota in these areas needs to be done. Moreover, by introducing a new species into the water of GMR, this will have an impact on the elimination of endemic species, which in turn can lead to the loss of this population. 


\section{Activities contributing pollutant waste}

Total Suspended Solids, almost all stations of SubDrainage Basin estuaries exceed Water Quality Standard (WQS/BMA), which means that the tidal waves on reservoir bring the solids which are eroded when the water flow back into the reservoir. BOD is high at all stations and at all time of the study, indicating a large number of organic waste that goes into the waters of the reservoir so that the metabolic activity of aquatic organisms is increased, which in turn the content of BOD will be increased too. The high number of COD at some stations is due to the large number of organic materials which are hard to be decomposed by aquatic organisms, so the decomposing process is done through a chemical reaction. The emergence of $\mathrm{Cu}$ and $\mathrm{Zn}$ in most research stations is happened at the first sampling (March 2011). This is probably due to industrial activities on land at the upper course which produces $\mathrm{Cu}$ and $\mathrm{Zn}$ waste and disposes them directly into the river, which in turn they will flow into the water of GMR.

The presence of Escherichia coli exceeding Water Quality Standard (WQS/BMA) class 2 (PPRI No. 82 of 2001) was possibly due to the activities of farmers that throwing their excrement to the water of river at the time they worked on their lands. But this situation is no longer happened now, as the dry season comes, agricultural activities are decreased causing land processing activities are also reduced; often the land is left fallow.

Tourism activities and aquaculture (KJA) also gave significant contribution especially the high number of BOD. Based on the results of the calculation of $\mathrm{DO}$ value that is high, the amount of BOD and COD does not preclude the availability of oxygen dissolved in the water, so it will not interfere the life of aquatic biota.

From the description above, the conclusion is as follows: Pollution of the waters of GMR is the pollution with the status of light-moderate-heavy. Activities that potentially give great contribution in water pollution of
GMR are households and activities outside GMR. To manage this reservoir as an ecosystem cannot be done partially, the reservoir has to be considered as part of the Drainage Basin (DAS), Drainage Basin (DAS) approach in an integrated manner in the management of the reservoir covers aspects of Catchment Area (DTA) conservation and control of dilapidating force of water in the reservoir. It still needs deeper study of the quality and quantity of water GMR, to determine a management model which is appropriate, sustainable and environmentally friendly.

\section{REFERENCES}

Alaert S, Santika SS. 1987. Methods in Water Research. Usaha Nasional, Surabaya. [Indonesian]

AOAC [Association of Official Analytical Chemists]. 2005. Official Methods of Analysis of AOAC INTERNATIONAL, 18th ed. In: Horwitz W, Latimer Jr GW (eds). AOAC International, Gaithersburg, MD, USA.

APHA [American Public Health Association]. 1995. Standart Methods for the Examination of Water and Weste Water. 17 ed. American Public Health Association, Washington DC.

Bapedal. 1994. Standart Nasional Indonesia; pengujian Kualitas Air, Sumber dan Limbah Cair. Direktorat Pengembangan Laboratorioum Rujukan dan Pengolahan Data, Badan Pengendali Dampak Lingkungan. Jakarta.

Boyd CE. 1982. Water Quality Management for Pond Fish Culture. Elsevier, New York.

Effendi H. 2003. Assessing Water Quality for the Management of Resources Water and Environment. Kanisius, Yogyakarta. [Indonesian]

Faculty of Geography UGM and SBRLKT Solo. 1996. Evaluation Report of Reservoir Park and the Influence of Land and Soil Rehabilitation Project in Wonogiri. Sub Balai Rehabilitasi Lahan dan Konservasi Tanah, Surakarta. [Indonesian]

KepMNLH Nomor 115 tahun 2003. Guidelines for Determination of Water Quality Status. [Indonesian]

PPRI No. 82 of 2001. Management of Water Quality and Water Pollution Control. [Indonesian]

Sudibyakto HA, Suprayogi S, Widiyanto, Sudaryatno, Pitoyo AJ, Senawi, Sartohadi J, Muita'ali L, Murti SH. 2005. Details Plan Preparation for Environmental Management of Upstream Watershed. PT. Arcapada Hasta Tunggal, Yogyakarta. [Indonesian] 